Александар М. Милановић*

Универзитет у Београду

Филолошки факултет

Катедра за српски језик

са јужнословенским језицима

https://doi.org/10.18485/ai_petrovic_goran.2020.ch9

821.163.41.09 Петровић Г.

811.163.41'38

\title{
СТИЛСКИ ОБЕЛЕЖЕНА ЛЕКСИКА У РОМАНУ АТЛАС ОПИСАН НЕБОМ ГОРАНА ПЕТРОВИЋА
}

У раду се анализирају стилске функције застарелих речи (архаизама и историзама) и индивидуалних неологизама (потенцијалних речи и оказионализама), као и стил-

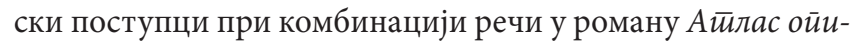
сан небом (1993) Горана Петровића. Кроз анализу функција у тексту, утврђују се висока стилогеност и стилематичност свих стилски обележених лексема, као и ефектност поступака разградње колокација и фразеологизама, а Петровић се позиционира као један од водећих стилиста међу савременим српским прозним писцима.

Кључне речи: архаизам, историзам, индивидуални неологизам, потенцијална реч, оказионализам, колокација

0. Анализа било којег сегмента језика књижевности подразумева „завиривање у пишчеву лабораторију”. Овај безброј пута понављани метафорични израз може се схватити и готово буквално. Писац ових редова имао је више прилика да завири у „лабораторију” Горана Петро-

* aleksandar.jus@gmail.com 
вића. Понекад метафорично, читајући на пример рукопис Скеле и дајући одређене сугестије или разговарајући о различитим језичким питањима, а понекад и буквално, разгледајући Петровићев радни простор, собу испуњену речницима који се писцу налазе надохват руке. И без таквих увида, дакле само на основу читања његове објављене прозе и поређењем са прозом његових савременика, писац ових редова тврди да је Горан Петровић несумњиво најйроїрамиранији савремени српски прозни писац. Реч йроірамиран овде не треба прочитати као реч са негативним конотацијама. Напротив, Петровић је писац који пише са јасним књижевним програмом, али и са јасним језичким програмом, као и са јасним механизмима за остваривање тих програма. Развијени и успешно остварени програми, наравно, не умањују нити ниште потребу за неопходним књижевним надахнућем, али су, сматрамо, нужан предуслов да од етеричног надахнућа добијемо и конкретно дело са уметничким квалитетима.

Саображеност Петровићевог језика са тематиком дела и природом књижевних јунака и ликова у њему најлакше се, наравно, може проверити на синтаксичком и лексичком плану. Уколико упоредимо језик и стил у објављеним Петровићевим делима, без већих тешкоћа ћемо и у синтакси и у лексици запазити одређене константе, али и непрекидне промене условљене тематиком дела, позицијом приповедача и разноврсношћу свих параметара који условљавају језик и стил у исказима јунака и ликова (средина, узраст, пол, образовање, социјални статус и сл.). Петровић се, наиме, језички и стилски непрекидно прилагођава: теми у делу, одабраној епохи, типу приповедача, карактерима јунака и ликова чија је палета готово бескрајна.

1. Циљ овога рада јесте да се у литератури устаљени судови о богатству и разноврсности Петровићевог језика провере при анализи активиране лексике у роману 
Айлас ойисан небом, објављеног 1993. године. ${ }^{1}$ Пре саме анализе, ваљало би нагласити да је, као и у другим Петровићевим делима, граница између стилских и функционалних домена лексике и граматике веома танка, и да овај писац управо рачуна са стилским ефектима које може постићи поетичким активностима у том граничном подручју. Примери су бројни, а навешћемо само поједине, најфреквентније. Ефектност многих изабраних лексема, на пример, открива се тек при судару семантика у неочекиваним лексичким спојевима у синтагмама, дакле синтаксичким јединицама. Друго, изражен стилски ефекат у овом роману добија се и разбијањем, декомпоновањем колокација и фразеологизама, што је поступак који такође нераздвојно спаја лексику (у ширем смислу, са фразеологијом) са синтаксом. ${ }^{2}$ Треће, честе су и поетичке игре и поигравања са деминуцијом, а деминутиви и хипокористици опет су на самој граници лексике и граматике, сада творбе речи, дубоко уроњени у експресивност и емоционалност. ${ }^{3}$ Деминутиви и хипокористици

1 Сви примери у раду биће наведени према издању Народне књиге и Алфе из 1998. године.

2 Уп. веома ефектан пример поигравања значењем фразеологизма: природа неких људи не разликује тренутак када језик треба крити иза зуба од тренутка када језик ваља држати за зубима (193). Примери декомпоновања колокација следе у раду.

3 Иако је ово тема за посебан рад, ради илустрације навешћемо само први пут потврђене лексеме, које се неретко понављају (неке и више, па и много пута), у Айласу: часак 15, стручак 15 , фигурица 17, каменчић 24 , мрвица 24 , врећица 34 , стварчица 35 , пужић 35 , љуспица 36, пахуљица 36, душица 36 , капљица 37 , листић 41 , рибица 44 , теглица 44 , рупица 49 , животињица 51 , кутијица 51, пакетић 51, мехурић 51 , сточић 52 , куглица 53 , врећица 53 , чворић 55 , бочица 63 , снопић 63 , цедуљица 63 , бродић 69 , гранчица 70, хлепчић 73 , дрвце 75 , капљица 77 , комадић 77, лоптица 78, кашичица 87 , кућица 91, венчић 91, трачица 95, жбунић 95, машница 96, кончић 96, стазица 96, 
нераскидиво су преплићу у роману Айлас ойисан небом, о чему најубедљивије сведоче наизглед плеонастичке синтагме: малени комаguћ (маленим комадићима свежине хладило се чело 135), сићушна ирвена йачкииа (666 сићушних црвених тачкица 143) и сл. Неретко Петровићево попридевљавање глаголских прилога садашњих, као четврто, односно често активирана лексикализација као тип творбе речи, опет доказује пишчеву намеру да непрекидно своја решења налази захватајући истовремено и из лексичких и из граматичких стилских резерви. ${ }^{4}$

путић 103, смешак 104, Сашица 109, оделце 110, пламичак 113, тачкица 118 , часак 120 , саксијица 123 , трунчица 127 , тањирић 128 , стварчица 129, ексерчић 130, длачица 131, барица 133, свежњић 137, шољица 138, зубић 139, делић 140, клобучић 143 , иглица 143 , облачић 147 , жилица 183 , метлица 186 , букетић 187 , мрежица 207, корпица 207; гребуцкање 87, стругуцкање 87, трљуцкање 87; црвенкаст 75, мајушан 81; куцкати 75, сипкати 81 . Насупрот њих, аугментативи и пејоративи врло су ретки: травуљина 100.

4 О стилским аспектима употребе глаголских прилога у Петровићевомјезикув. радМилоша Ковачевићауовом зборнику. Не чуди што висока фреквенција глаголског прилога садашњег и жеља за кондензованим исказом доводи до попридевљавања: пратећи ефекат 40 , навирућа страст 40 , одлазећи месечев зрак 46 , долазећи сунчев зрак 46, одговарајући зид 52, запрепашћујући феномен 60, навирућа ноћ 61, зачуђујућа уједначеност 64, Ваздух је био омамљујући 64, наступајући векови 73 , просијавајући остатак 76, претећа писма 84, идући понедељак 103, непостојеће семе 122 , непостојећи пут 124, непостојећи град 124, непостојећа најезда 124 , непостојећа земља 124 , владајући кругови 124 , компромитујуће зрно 133, будући успех 136, обећавајућа романса 154 , пулсирајућа опна 160, будући дан 160, будући намерник 163 , лебдећа палата 164, претеће писмо 171, следећа ноћ 172, лебдећа колиба 173, притискајућа Празнина 182, преклињући звук 197, пратећи прибор 206, одговарајућа мрежица 207, непостојећи ормар 212, непостојећи сто 212, лебдећи портал 214; разликује постојеће од непостојећег 123, у основи свега постојећег и непостојећег 187. Уп. кондензованост у следећим примерима: У следећој секунди, не марећи за могућу опасност, притрчавамо и ми (71), посматрајући је сасвим очарану будућим сусретом (102). 
Петровићева машта (или фантазија), као у књижевној критици стално наглашаван квалитет његових дела, потврђује се не само на тематском или сижејном плану већ и при анализи лексике у роману Айлас ойисан небом. Маштовитост је Петровић демонстрирао како на плану селекицје тако и на плану комбинације лексике, али и на плану иновације. Ако бисмо селекцију, наиме, описали као избор из постојећих могућности (одабир стилски неутралне или обележене лексике), онда бисмо нарочито у језику књижевности морали истаћи и чест моменат лексичке иновације, отелотворен у бројним индивидуалним неологизмима, било да су из сфере оказионализама или сфере потенцијалних речи. Коначно, комбинацију сагледавамо управо у семантички ефектним синтаксичким јединицама, пре свега у синтагмама, али и реченицама.

2. По различитим критеријумима маркирана лексика једно је од типичних стилских својстава Петровићеве прозе. И Айлас ойисан небом пример је складног споја по пореклу или употреби хетерогене лексике. Склад је, наравно, постигнут мотивисаношћу избора. Тако су историзми и архаизми који коегистирају са необележеном лексиком у роману својство углавном „цитата” измаштаних историјских докумената, што је једно од стилских својстава постмодернистичке прозе, а неологизми опет својство маштовитих исказа наратора, односно последица фантастичног света у којем обитава.

Застарела лексика у Петровићевим романима махом је плод истрајне претраге по речницима и пажљиве селекције, а поједине речи из старине српске као да су другим путевима тражиле писца, а не писац њих. ${ }^{5}$ Beћ је

5 Вредну илустрацију понудио је током скупа у Андрићграду са̂м Петровић, испричавши како је, привучен звуковном страном тј. еуфонијом, антропоним Жаж из Дечанске хрисовуље унео у Ойсаgу

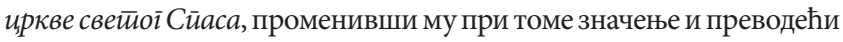
га у сферу апстрактних именица у синтагми жаж сунца. 
у литератури констатовано како Петровић радо посеже за застарелом лексиком, историзмима и архаизмима, у делима са историјском тематиком (Милановић 2000, Милановић 2003). И у роману Айлас ойисан небом застарела лексика заузима битну стилистичку позицију, она је не само стилогена него и стилематична јер преузима функцију маркера псеудоцитатности. Већ на самом почетку романа, у првом уоквиреном псеудоцитату који прати „Слику 1.” текст је архаизован синтаксички и лексички, што ћемо илустровати почетном реченицом: „Вредан је пехара навршитог искреним признањем добар обичај старих картографа да пре него што се лате писања на првом листу стрпљиво 'покусе' перо (7).” У „Речи захвалности” Картографа, једног од јунака романа, појављује се архаична лексема звезgочай $а и$, у напоредном низу са више неочекиваних занимања, али исказаних необележеним лексемама (да свесрдну помоћ нису пружили кустоси, алхемичари, картоманти, историчари, шамани, музиколози, астрономи, фотографи, орнитолози, звездочатци 16) као битно обележје картографовог писаног стила. Чињеница да није активирао савремену реч астиролої, али такође ни поједине архаичне синониме или творбене дублете наведених речи, на пример йовесничар или истиорик м. исӣоричар, сведочи о Петровићевој намери да сасвим благо обележи Картографов језик. Дочаравање „аутентичности” измишљених текстова из старијих епоха неретко почива, уз застарели ред речи, управо на активирању архаизама: мухамеgанаи, (На тло Сицилије искрцало се још седам младих мухамеданаца 25), іотиовитии и мухамеgански (која ће готовити јело по мухамеданском обичају 25), īocūa (У то доба госпе града Палерма [...] надмашише у отмености чак и госпе из града Сијене 26), јануариј и сербски (19. јануарија 1785. Захарија Стефановић Орфелин [...] први сербски картограф [...] заспао је 31), алајли барјак (Уз алајли барјаке из 
Бурсе 46), налокнан (Мало је познато да краљ Луј XIV, поред заљубљености у мирисне марамице и налокнане перике, беше страсно одан и обичној игри кликера 53), корачај (Ту, на пар корачаја од нас, он је у једној руци стезао шкољку 57), мољеније (Неко је полугласно говорио као кад се чита мољеније 57), аніел (Када синови човечији небом ангеле почеше ловити због пера његових меких, Господ се разгневи 126), војна (Беху се узели тек седмицу пред војну 152) и сл. Исту функцију актуелизације имају и историзми: йочелища („Почелица султаније Оливере” 10 , Почелица од копаоничког месеца и сунца остаде као награда неког Турчину Ајдину 46), ковча (те он само начини ковчу и султанија Оливера доби почелицу 46),

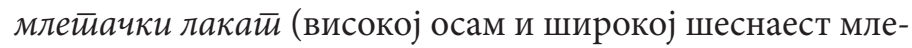
тачких лаката 27) итд. Ови графички уоквирени текстови доносе и праве затурене лексичке бисере, попут деми-

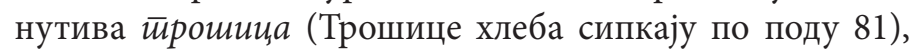
са значењем 'мрвица', остварен и као прилог тирошице у значењу 'сасвим мало, нешто мало, мрвичак', потврђен у Вуковом Срйском рјечнику (РМС).

Архаизми се, међутим, појављују и у нараторовом тексту, на пример неразбор (пред тежином неразбора 18), замаїлица (Занавек је остало обавијено замаглицом 58), $\bar{u}$ исме (На њој су нека, нама непозната писмена 71), злокобииа (показују знаке добре воље да се растану од сопствене злокобице 83), заслушайи (гласом у који се сваки мушкарац заслуша као да са њим иде и власница 133), ${ }^{6}$ ogбеілица (три одбеглице са машне 158), муйнило (И сама река се претвори у мутнило 195) и сл., а ретко чак и у насловима поглавља, као у случају именице указаније (Указанија тетка Деспине, прекомерна уредност фризуре и пролећни радови 32). Замагљено значење историзама

6 Овај глагол потврђен је у РМС само примером из Вуковог Срйскої рјечника, са значењем 'зачути'. 


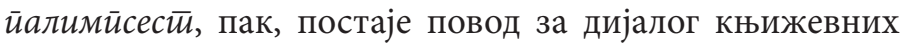
јунака у којем се позната метафора из српске културе (уп. „живи палимсести”) додатно проширује:

Срећом, данашњи начин штампе није тако савршен рекао је Старац када се сасвим приближио. - А и како би један палимпсест могао да се изради на машини.

Палимпсест? - поновио је Драгор.

Да, палимпсест - осмехнуо се Старац. - Књига са бесконачним бројем текстова, писаних један преко другог, али увек тако да све претходне и будуће речи могу бити прочитане (63).

3. Упркос богатству различитих стилских резервоара, Петровићеву фантазију не може задовољити постојећи српски лексикон. Стога он и у овом роману гради бројне индивидуалне неологизме, крећући се у распону од потенцијалних речи које се складно могу уклопити у постојећи систем па до свесно грађених оказионализама, којима смело крши постојећа творбена правила. Већину новостворених речи, ипак, чине изведенице и сложенице грађене по постојећим творбеним моделима. На овоме месту ваља додати да ексцерпција Петровићевих неологизама код истраживача обнавља теоријско-методолошке потешкоће познате из литературе. Наиме, поједини примери заиста се налазе на граници између ковања индивидуалног неологизма и активирања ретког и заборављеног поетизма, а најбољи међу њима је пример именице $g p x \bar{u} y p$. Активирајући редак поетизам $g p x$ $\bar{u} y p$, потврђен само једним примером у РМС са значењем 'дрхтавица', Петровић се поиграва и са хомонимијом као стилски потентним значењским односом, дајући реткој речи нова, при томе различита значења (младеж у облику листића биљке дрхтур 41: држи перо дрхтур ивица 223, одмара своје дрхтур ивице 224). 
3.1. Петровићеве новосковане изведенице по правилу су грађене аналошки према постојећим српским речима и најчешће им се лако препознаје непосредан узор, што им обезбеђује семантичку прозирност чак и ван контекста. У бројним примерима препознајемо и утицај српске књижевне традиције, односно српске лектире која је формирала писца Петровића, и ваља их схватити и као омаж историји српске књижевности. Такви могу бити они са архаичним призвуком, на пример изведени нултим суфиксом или суфиксом - $a j$, налик на романтичарске неологизме (Ристић 1969, Ковачевић 2012).

Појединим неологизмима Петровић сјајно попуњава празнине у систему, што указује да је пажљиво консултовао речнике и тражио оригинална а системска решења. Тако гради именицу чамой (без страха би се отиснуо у чамот Града 90, неколицина запослених је у чамот Града свакодневно слала стотине венчића 91), практично скраћивањем именице чамотииға, иако у систему већ има и необележено чама и песничко чам (РМC). Нулти суфикс имамо у необичном облику светллуи (Било је доста људи без сенке, магличасте туге, светлуца среће 98), иако је у песничком језику већ остварен облик светлуиај са значењем 'тренутна светлост, одсјај, обично слаб, кратак' (РМС). Ефектан неологизам йрхйај (под мишку прхтај голуба 36), изведен суфиксом - ај, корелира са другим сродним примерима у роману: поред необележене именице yguсај (Природно, овај удисај мора да буде тих и брз 82; Он личи на удисај очајника 82), писац активира и данас већ помало архаичну именицу guсај (Као последњи дисај, стечен страховитом муком, а онда великодушно препуштен витком телу кларинета 83).

Суфиксом -ишие е Петровић изводи индивидуалне неологизме йрилазишӣe (заговорника затворених и отворених прилазишта 68) и ӣролазишйе (да људе лиши знања где је пролазиште из света у свет 156, у луку про- 
лазишта се стиже из другог правца 208), додајући им опет у пажљиво грађеном систему, као контратежу, још и архаичну лексему кровишие е (дугачка ужад паучине расплетене по кровиштима 21). Суфиксом -ица изграђена је именица забуница (Старац стрпљиво броји, из браде прстима леве руке тера забунице, изнова процењује ону невелику књигу „Атлас” 224), а контекст показује да у питању није деминутив именице забуна, већ индивидуални неологизам са значењем 'мисао тј. идеја која уноси забуну'. Карактеристичан покрет руком при размишљању Петровић је као слику преточио у нову реч.

Петровић је талентовани мајстор за проналежење нових лексичких решења која уносе нову значењску нијансу коју постојеће речи, помало и истрошене од употребе, немају. Тако суфиксом - ии, од предлошко-падежне конструкције гради изведеницу безречица (па окренусмо и ми да ћутимо делећи безречицу 167), којој је значење конкретније, опипљивије од апстракције постојеће име-

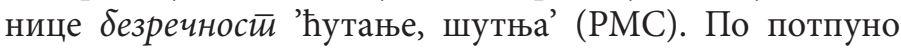
истом творбеном моделу настала је и именица безнаguиа (Тамо се насељавају прошлост, безнадица, меланхолија и жалост 168), а и њен однос према постојећим делимичним синонимима безнаgност, безнађе, безнаgежносй (РМС) остаје исти, на релацији конкретније : апстрактније. Продуктивност овог творбеног модела у Петровићевом језику потврђују и именице нерасйознајнииа (тек неколико метара изнад тужне нераспознајнице 18), невияица (Ботанички одсек Академије за невидице, Љењинград 131) и нечујииа (ветар је носио њене речи право у вирове нечујице 194). Стварањем неологизма невияица Петровић је додао још један синоним пару невияелница и невияело, са значењем 'мрак, тама; мрачан простор', док је аналошки грађеном именицом нечујииа попунио једну системску лексичку празнину у српском језику (невидица : нечујица), којом конкурише 
необележеној именици $\overline{\boldsymbol{u}} и и н а .^{7}$ Изведеница стиаровремаи (Атињани, Лакедемонци и наши старовремци 106), са синтагмом у основи, прозирне је семантике, а граматички подржан помало застарелим придевом и прилогом стиаровремски (РМС).

3.2. Сложенице Петровићу дају још већи простор за језичку креативност. Поигравајући се са придевом сйороі̄oрећu, непотврђеним у РМС упркос распрострањеном термину сйороїорећи жйайин (коришћеном и у JНА), Петровић гради придеве брзоживећи (брзоживећи људи, хитро и страсно прођу 114) и сйороживећи (да се спороживећи људи пате или муче 114). Према великом броју сложеница за првим елементом широк-, Петровић гради ширококрил (Једне ноћи Ширококрила птица испусти из својих канџи тако велику грудву земље 156). И сложеница мекойамучан (Као да је неко горе умотавао и размотавао мекопамучне нити снега 157), као и друге сложенице, чини се да додатно архаизује Петровићев језик, приближавајући га епохама када су оне, под утицајем црквенословенског језика, биле чешће у језику српске прозе.

3.3. Као и у случају сложеница, и новосковане речи добијене комбинованом (сложено-суфиксалном) творбом, указују на Петровићеву потребу да се фонд постојећих лексема допуни блискозначницама које ће нијансирати поједина значења, али и на потребу да се створе сасвим нове речи за сасвим нове појмове. Тако наспрам новосковане речи іризоgушица (Смрт звана Гризодушица има споре ципеле 19), системски грађене као превладавање и нијансирање апстрактнијег творбеног дублета іризоgушје, стоји реч рейоіризаи, (а да ниси свестан, да си и сам репогризац 65), која нема лексички, творбени ни семантички еквивалент у српском језику.

7 Именица нечујносй има другачије значење, 'особина чега да се не чује' (РMC). 
3.4. Петровићеви индивидуални неологизми из домена потенцијалних речи, добијени различитим творбеним типовима, неретко су у атрибутској функцији, за шта је модел могао наћи у романтичарској поезији. Тако је и један такав пример заправо преузео од Лазе Костића: лексему неgозив из именичке синтагме сан неgозив (заспао је сав у грозници сном недозивом 31) потврђује и РМС са значењем 'место где не допиру позиви', али само са једним Костићевим примером (Одох сад у недозив!). Романтичарског духа су и друге Петровићеве кованице у атрибутској

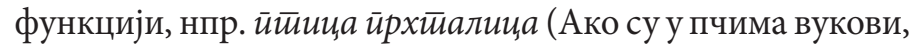
нема могућности да се они замене птицама прхталицама 100) или леййup јеgноноћаи (попут лептира једноноћаца 114). Није случајно што су у истом типу именичких син-

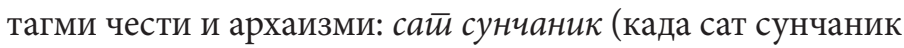
већ почиње да застајкује 70, Сваке ноћи кваре сат сунчаник 127, свако јутро изнова поправљају сат сунчаник 128, сат сунчаник није радио већ седам часова 138 , сат сунчаник је одбијао да ради 202), ${ }^{8}$ збуюени осмех завезак (уз усне му је стајао збуњени осмех завезак 202) и сл.

4. Најплодније тле Петровићеве лексичке креације, међутим, нису његове потенцијалне речи, већ оказионализми, у којима је пишчева језичка игра на врхунцу, као и слобода у рушењу народним и стандардним језиком прописаних граница. Чини се да је неспутана језичка

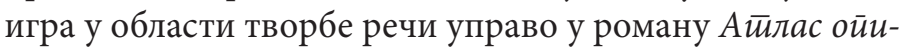
сан небом достигла врхунац у целокупном досадашњем Петровићевом опусу. Сложенице налик на надреалистичке експерименте, у којима доминира сликовитост поређења додатно су наглашене стилским поступком кумулације на више места у роману.

8 У роману нема данас уобичајене синтагме сунчани сай, а појављује се и маштовита конструкција сай на месечину (удобнију одећу, обућу, сат на месечину 170). 
Већ први у тексту груписани примери блистиаво-

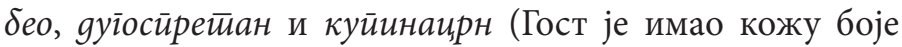
багремовог меда, блиставобеле зубе, дугоспретне прсте и купинацрну косу што му се дирала са раменима 49) указују на суштину Петровићеве игре. Он значење постојећих придева жели прецизирати, крећући се простором од очекиваног и потврђеног (блистиавобео) до

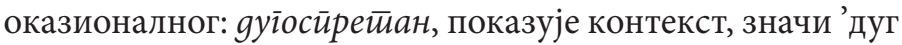
и спретан', а куйинацрн 'црн као купина'. Ова игра напредује у другој скупини кумулисаних придева, у којој се налазе gалекоблакбео, морскоянойлав, башужасирн, оро-

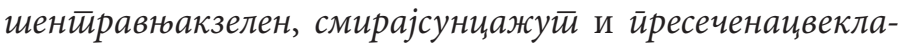
ирвен (па широким потезима наставља да наноси боје на платно. Далекоблакбеле, морскодноплаве, башужасцрне, орошентравњакзелене, смирајсунцажуте - прште на све стране 61). Описујући чин стварања уметничке слике, Петровић оказионалним лексемама дочарава нијансе боја на уметниковом платну за које српски језик, као ни други језици, нема одговарајућа имена, а које у писцу, иако измаштане, буде посебну креативност. Занимљиво је да у примеру башужасирн као да осећамо и призвук колоквијалности јер је писац избегао за нијасну стилски

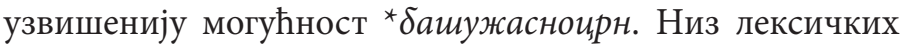
иновација за прецизирање боја настављен је на следећој страни романа придевом ӣролећнонебойлав (За нијансу пролећнонебоплаве мирнији он пали лулу и полако прикупља расути прибор 62), а последњи пример високонебойлав (Каталогизација високонебоплавим мастилом 223, зделица са високонебоплавим мастилом 223, до вира високонебоплавог мастила 223, у здели високонебоплавог 224) стоји усамљен при крају романа, али више пута поновљен, што је, после кумулације, нови стилски поступак интензификације оказионалних творевина. ${ }^{9}$

9 Наспрам наведених примера стоји другачији, у којем име боје 
5. Као и у области ковања оказионализама, Петровић се у области непоновљивог стваралаштва у језику потврдио и на оси комбинације, показујући да је спајање неспојивог или тешко спојивог могуће унутар једне речи, али и у синтагматским спојевима, па и у реченицама. Иксористивши и звучне ефекте редупликованог краја именица, Петровић гради специфични синоним за сйан

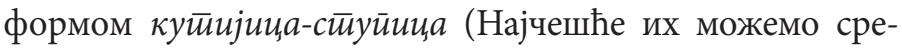
сти на обалама река, у поподневним часовима, док други свет чами у својим кутијицама-ступицама 22). Примери фантастичних спојева у именичким синтагмама нижу се читавим романом па би и пуко навођење свих примера подразумевало рад далеко већег обима. Зато ево само

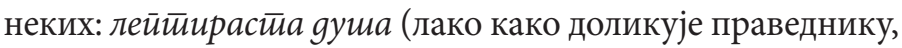
препушта своју лептирасту душу јави 31), каменолом иесама (После дугог и заморног пута [...] стижем до каменолома песама 95), хиљаgуїодиньа ӣойлава оілеgала (На жалост, у хиљадугодишњој поплави огледала научених да повлађују својим власницима, та посебна врста огледала се изгубила 188), йлићак јасӣука (Више плићака јастука, дубље од снова, кроз плаво, лађом папира 213).

Нарочито су ефектне синтагме које настају поступком разбијања колокација сасвим неочекиваним конкурентима: четиири іоguшюе болестии (наслов: Четири

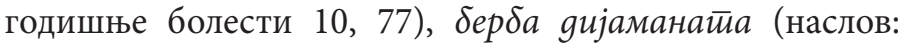
Берба дијаманата 10, 75), окрајак вейрова (Током 1586. године преко тридесет каравела великог газа је на докове Малаге, Кадиса и Валенсије искрцало стотине хиљада хвати окрајака ветрова Карипских острва 135), буке$\bar{u} u \hbar$ изненађена (За букетић изненађења је различитост личности у свакоме од нас 187), музикалне іруgu (Имати

није експлицитно исказано: крат̄ка лешник коса (Лузилда, сада сасвим јасна, девојка дугих трепавица и кратке лешник косе прича о свом трагању за Драгором 137). 
музикалне груди, бокове, мишице (или колена и лактове како примећује М. В, Љоса) - за једну жену ипак није нешто чудно 125) и сл. Овај поступак сасвим је сличан поступку замене лексичких елемената у фразеологизму, чему је Петровић прибегао само једанпут, варирајући фразеологизам йоћи за руком песничком конструкцијом йоћu за јеgрима (пре вести да је једној лађи пошло за једрима да оплови свет 209). ${ }^{10}$

Бег од устаљеног у језику, поигравање са њим у циљу постизања свеже језичке слике, у Петровићевом роману се може илустровати и на реченичном новоу. Тако је лексичким варирањем веома ефектно разградио устаљене

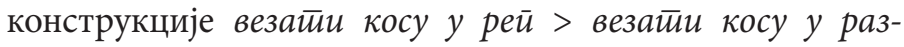
мишаљаюе (Драгор је косу везао у размишљање 49) и

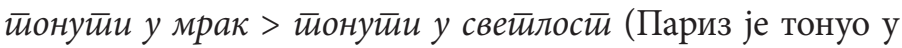
своју светлост 183), рачунајући и на друге ефекте које су лексичке измене унеле у семантику конструкција: у првом примеру изазване пребацивањем из сфере конкретног у сферу апстрактног и фантастичног, а у другом стварањем парадоксалне слике везане за „град светлости”.

6. Сваки читалачки сусрет са прозом Горана Петровића, па и научни скуп организован у Андрићевом институту 2019. године, уверавају нас додатно у ставу да његов језик и стил заслужују монографски опис. Упркос бројним радовима, још увек увиђамо само фрагменте целине. Богатство грађе при сваком селектованом проблему из области лексике или синтаксе приморавају истраживача да се ограничи и у захвату и у навођењу ексцерпираних примера. Пројектовање и мозаичко склапање сваке реченице текста попуњавањем свих позиција у структури пробраним речима, као и корелације у које са остатком

10 Петровићева конструкција као да израста из поигравања са стереотипом из фудбалских извештаја йоћи за ноїом, тј. из ироничног отклона према њему. 
текста улазе и написане реченице и њени делови, сведоче о огромном Петровићевом напору да српски језик проговори на посве нов начин у његовим делима. Стил савремене српске прозе у његовим делима је на врхунцу. Ретки су данас такви прозни писци.

\section{ИЗВОРИ}

Горан Петровић, Айлас ойасан небом, Београд: Народна књига / Алфа, 1998.

\section{ЛИТЕРАТУРА}

Драгићевић 2018: Рајна Драгићевић, Срӣска лексика у йрошлостии и gанас, Нови Сад: Матица српска.

Ковачевић 2012: Милош Ковачевић, Линівостиилистиика книжевноі $\bar{u} е к с \bar{u} а$, Београд: Српска књижевна задруга.

Милановић 2000: Александар Милановић, „Стилематичност архаизама у роману 'Опсада цркве Св. Спаса' Горана Петровића", Повеља, 1, Краљево, 120-130.

Милановић 2003: Александар Милановић, „Архаизовани језик савремене српске прозе”, у: Савремена срйска йроза, 15, Трстеник, 123-142.

Ристић 1969: Олга Ристић, „Лексичко-семантичке одлике творбе именица у неких српских и хрватских романтичарских песника", Јужнословенски филолог̄, XXXVIII, св. 1-2, 219-320.

РМС: Речник срйскохрвайскоїа книжевной језика, 1-6, Нови Сад - Загреб: Матица српска - Матица хрватска, 19671976. 
Aleksandar M. Milanović

\section{STYLISTICALLY MARKED LEXEMES IN THE NOVEL ATLAS OPISAN NEBOM BY GORAN PETROVIĆ}

\section{Summary}

The paper presents the stylistic analysis of the obsolete and archaic lexemes (archaisms and historisms) as well as individual neological coinages and formations in the novel Atlas opisan nebom (1983) by Goran Petrović. The analysis is based on frunctional criteria which help determine the stylogeny and stylistic charge of the stylistically marked lexemes in the novel. The findings of this study rank Goran Petrović among top literary stylists in Serbian contemporary prose.

Key Words: archaism, historism, potential word, collocation, nonce formation, individual neologism. 